\title{
Penanaman Nilai-Nilai Kasundaan Berbasis Pembelajaran Tari Pakujajar di SMP Negeri 5 Sukabumi
}

\author{
Ayu Vinlandari Wahyudi, Tati Narawati, Trianti Nugraheni \\ Program Studi Pendidikan Seni \\ Sekolah Pascasarjana Universitas Pendidikan Indonesia \\ Jalan Dr. Setiabudhi No.229 Bandung 40154 \\ Email: ayuvw.vw@gmail.com
}

\begin{abstract}
This research aims to inculcate kasundaan values that is cageur, bageur, bener, pinter, singer that have been disappeared from students life. The decline of local cultural values creates problems, as well as moral degradation following the decrease of ethics and aesthetics values. This research consist of two steps include an analysis to the dance by using etnochoreology, etnopedagogy and folklore. Meanwhile, the implementation of dance learning uses a Lickona and Gardner theory. The results of studies show that the values contained in the dance pertains to cageur, bageur, bener, pinter, tur singer and these values are implemented through an ethnic dance learning that is Pakujajar Dance by using a sinectic learning model. This research employ an action research method with a qualitative approach. Based on the processes that have been done, there is a significant increase shown by improvement in imagination and understanding of the students to the subject materials, as well as student's attitudes of caring and mutual respects both to their teachers and their peers. This research produces the ethnic dance learning model.
\end{abstract}

Keywords: kasundaan values, pakujajar dance, implementation of dance learning

\begin{abstract}
ABSTRAK
Penelitian ini bertujuan untuk menanamkan nilai-nilai kasundaan yaitu cageur, bageur, bener, pinter, singer yang telah luput dari kehidupan para siswa. Terkikisnya nilai-nilai budaya lokal menimbulkan permasalahan, yaitu degradasi karakter yang dipengaruhi oleh lemahnya etika dan estetika. Penelitian ini terdiri atas dua tahapan, yaitu mengkaji tari dengan menggunakan teori etnokoreologi yang dibantu dengan pendekatan etnopedagogik dan folklor, serta implementasi pembelajaran dengan menggunakan teori Lickona dan Gardner. Hasil kajian diperoleh bahwa nilai-nilai yang berkenaan dengan nilai cageur, bageur, bener, pinter, tur singer yang kemudian diimplementasikan melalui sebuah pembelajaran tari etnis, yaitu tari pakujajar dengan menggunakan model pembelajaran sinektik. Penelitian ini menggunakan metode penelitian action research dengan pendekatan kualitatif. Berdasarkan proses yang telah dilakukan, terjadi peningkatan yang signifikan yang dibuktikan dengan meningkatnya daya imajinasi serta pemahaman siswa terhadap materi pelajaran dan sikap siswa yang peduli serta saling menghormati baik pada guru maupun antarsesama. Dengan demikian, penelitian ini menghasilkan model pembelajaran tari etnis.
\end{abstract}

Kata kunci: nilai-nilai kasundaan, tari pakujajar, implementasi pembelajaran tari 


\section{PENDAHULUAN}

Nilai merupakan pedoman bagi manusia yang terlihat dari segi sosial dan budayanya. Setiap daerah memiliki nilai-nilai yang dijadikan tolak ukur dalam berpikir dan bertindak bagi masyarakatnya, seperti halnya di daerah Sunda. Sudaryat (2015: 15) menyatakan bahwa masyarakat Sunda adalah kumpulan orang-orang Sunda yang dibesarkan dalam lingkungan sosial budaya Sunda, dan dalam hidupnya menghayati serta mempergunakan norma-norma dan nilai-nilai budaya Sunda. Budaya Sunda memiliki nilai-nilai budaya lokal yaitu nilai-nilai kasundaan yang dijadikan sebagai pendorong guna mencapai kesempurnaan yang dikenal dengan istilah "Gapura Pancawaluya” (Gerbang Lima Kesempurnaan). Istilah tersebut terdiri atas cageur, bageur, bener, pinter, tur singer. Dalam pembentukan nilai-nilai lokal ini diperlukan sebuah media yang dapat dijadikan sebagai pendukung, salah satunya yakni kesenian daerah setempat.

Kesenian daerah berpotensi dalam menerapkan nilai-nilai lokal. Banyak sekali kesenian yang terdapat di daerah Sunda. Salah satu contohnya yakni tari Pakujajar yang berasal dari Kota Sukabumi, Jawa Barat. Restela dan Narawati (2017: 187200) mengemukakan bahwa karakteristik sebuah masyarakat dapat ditelusuri pada salah satu cabang seninya, yaitu tari yang merupakan salah satu pernyataan budaya. Berdasarkan pernyataan tersebut, jelaslah bahwa suatu kesenian, khususnya seni tari dapat menjadi sebuah identitas atau pernyataan budaya dari suatu daerah, karena karakteristik masyarakat akan tercermin melalui tarian tersebut, baik dari segi gerak, musik, tata rias, tata busana, sejarah, atau fungsinya.

Pakujajar merupakan salah satu pohon yang berbentuk tegak lurus, panjang, bulat, dan keras. Pohon Pakujajar tersebut dapat dimaknai secara tekstual dan kontekstual.
Secara tekstual, pohon Pakujajar dapat dilihat dari bentuknya yang panjang, tegak lurus, bulat, keras, dan tidak bercabang banyak. Secara kontekstual, pohon Pakujajar tersebut memiliki arti harapan yang panjang, keras memegang cita-cita, keras memegang amanah, dan bulat tekadnya. Secara historiografi, Pakujajar adalah simbol, yakni apabila di suatu tempat terdapat pohon Pakujajar, maka daerah itu termasuk kerajaan Pajajaran.

Hal ini tercermin dalam cerita mengenai legenda kota Sukabumi, yang bermula ketika ada seorang pemuda gagah berani yang berniat untuk menolong kekasihnya yang akan dihukum mati oleh algojo. Pemuda tersebut tidak lain yakni Wangsa Suta. Wangsa Suta memiliki karakter pangger yang berarti karakter manusia yang kukuh, berdedikasi tinggi, berkomitmen, tangguh dalam membela kebenaran, dan tidak berkhianat. Sejarawan Anis Djatisunda dalam Firmansyah (2016: 39) menceritakan tentang legenda Kota Sukabumi yang mengisahkan tentang Nyi Pundak Arum dan Wangsa Suta. Dalam kisah tersebut diceritakan bahwa Wangsa Suta memberikan bisikan pada kekasihnya tersebut agar menunggunya di bawah pohon Pakujajar yang bercabang atau berdahan lima. Namun, setelah lama menunggu, akhirnya Nyai Pundak Arum tak kunjung datang untuk menemui Wangsa Suta. Kemudian Wangsa Suta menemui gurunya yang bernama Resi Saradea, yang berada di Gunung Arca, tempatnya tidak jauh dari Pasir Bedil atau berada di sebelah barat dari daerah Cijangkar, Nyalindung. Resi Saradea kemudian memberi saran untuk tidak menunggu dan mencari Nyai Pundak Arum karena dia sedang diutus oleh waktu dan diperintah oleh zaman. Sang Guru juga berpesan kepada Wangsa Suta agar menunggu waktu kembalinya Nyai Pundak Arum di Gunung Parang, yaitu saat Gunung Parang sudah dipenuhi oleh rumah dan Tegal Kole 
sudah berubah jadi dayeuh/kota (Firmansyah, 2016: 38-40).

Berdasarkan cerita legenda tersebut, tentunya terdapat nilai-nilai karakter yang terkandung di dalamnya. Cerita legenda kota Sukabumi merupakan landasan diciptakannya tari Pakujajar. Dalam mengupas nilai-nilai yang terkandung dalam tari Pakujajar, diperlukan sebuah teori yang mendukung, yakni teori etnokoreologi. Teori etnokoreologi menyatakan bahwa tari adalah sebuah produk masyarakat dan tari merupakan produk masyarakat yang mengandung nilai-nilai yang dianut masyarakat tersebut. Nilai yang dianut masyarakat satu dengan masyarakat lainnya berbeda. Kemudian, menilai dan mengapresiasi sebuah tari etnis tidak bisa berlaku umum melainkan harus dengan acuan nilai yang dianut masyarakat pemilik budaya tarinya (Narawati, 2013:70-71). Kajian tekstual dalam etnokoreologi berkaitan dengan karakteristik gerak tari, struktur koreografi, iringan musik, tata rias, dan tata busana. Rustiyanti, dkk. (2013: 42-55) menyatakan sebagai berikut.

"Analisis tekstual berisikan tentang pembahasan unsur-unsur suatu kesenian yang dapat menerangkan bahwa keseluruhan arti dan makna simbol dapat dibedakan, namun arti dan makna simbol-simbol itu tidak dapat dipisahkan."

Pernyataan di atas menjelaskan bahwa setiap kesenian memiliki arti dan makna simbol yang berbeda namun saling berkaitan satu sama lainnya, sehingga arti dan makna simbol tersebut merupakan satu kesatuan yang tidak dapat dipisahkan. Selanjutnya, Rustiyanti, dkk. (2013: 42-55) menyatakan bahwa analisis kontekstual terhadap seni tari artinya fenomena seni itu dipandang dengan disiplin ilmu yang didominasi ilmu antorpologi. Kajian kontekstual dalam etnokoreologi berkaitan dengan sejarah tarian, fungsi tarian, dan makna tarian.
Nilai-nilai kasundaan merupakan bagian dari nilai-nilai karakter yang tertanam dalam diri manusia, khususnya masyarakat Sunda, sehingga seyogyanya manusia harus berpikir dan bertindak sesuai dengan nilai budaya yang berlaku. Namun pada kenyataannya, dewasa ini, marak terjadi kasus-kasus negatif, khususnya di kalangan siswa sekolah, yang menyebabkan degradasi karakter. Hal tersebut disebabkan oleh kurangnya penanaman nilai-nilai karakter dan terkikisnya nilai karakter pada diri individu. Titik permasalahan lain yaitu kurangnya pengendalian etika dan estetika pada diri pada individu, khususnya bagi para remaja terhadap nilai-nilai lokal. Pengendalian etika dan estetika yang tidak stabil membawa para remaja pada pengambilan keputusan yang kurang matang. Dengan kata lain, para remaja lebih mudah terpengaruh karena respon dan emosi yang kurang stabil. Persoalan lain mengenai degradasi karakter yaitu mulai terkikisnya nilai-nilai budaya lokal, khususnya nilainilai kasundaan bagi para generasi penerus bangsa karena perkembangan zaman, seperti halnya kecintaan remaja terhadap modernisasi memberikan apresiasi yang lebih tinggi daripada kecintaannya terhadap seni tradisi. Dampak negatif dari terkikisnya nilai-nilai budaya lokal yaitu kenakalan remaja, kriminalitas, dan penyimpangan sosial yang kian marak menjadi perbincangan khalayak umum. Fenomena sosial tersebut dapat diantisipasi dengan proses pembelajaran yang baik dan optimal. Revitalisasi nilai-nilai karakter serta nilai-nilai lokal disinyalir dapat mengatasi berbagai macam persoalan sosial yang terjadi pada kalangan remaja khususnya bagi siswa sekolah. Adanya penanaman nilai-nilai kasundaan diharapkan mampu memberikan dampak positif terhadap perubahan tingkah laku serta pola pikir siswa.

Penelitian ini lebih menitikberatkan terhadap nilai-nilai kasundaan (cageur, bageur, 
bener, pinter, tur singer) untuk membangkitkan dan memberdayakan sistem budaya lokal (indigenous knowledge), teknologi lokal, kesenian lokal, kearifan lokal yang biasanya dianggap tidak ilmiah tetapi justru kaya atau kental kandungan nilai-nilai etika dan estetika budayanya. Nilai-nilai kasundaan perlu ditanamkan kembali agar siswa memiliki karakter yang sesuai dengan nilai-nilai budaya lokal. Dengan demikian, diperlukan adanya upaya untuk penanaman nilai-nilai kasundaan pada siswa, yakni melalui pembelajaran tari Pakujajar. Tari Pakujajar dapat dijadikan bahan materi pelajaran seni budaya di kelas IX Sekolah Menengah Pertama, terutama mengenai kesenian lokal yang di dalamnya terkandung nilai-nilai kasundaan.

Subjek penelitian adalah siswa kelas IX SMP. Hal ini merupakan fase yang tepat sesuai dengan rentang usia siswa kelas IX SMP, yakni fase remaja, karena fase remaja terhitung dari usia 12-18 tahun. Yusuf (2009: 26) mengatakan bahwa masa usia sekolah menengah bertepatan dengan masa remaja. Pada masa remaja, individu harus memiliki pertahanan yang kuat baik untuk tubuh maupun untuk jiwanya, karena pada masa tersebut rentan terhadap pengaruh-pengaruh yang datang dari luar dan masa tersebut dapat dipandang sebagai masa krisis penyesuaian.

\section{Teori Etnokoreologi}

Istilah etnokoreologi sudah tidak asing lagi dalam dunia tari. Pelopor istilah tersebut yakni Soedarsono. Narawati (2013: 7071) mengemukakan bahwa etnokoreologi berasal dari kata 'etno' yang berarti etnis, dan 'koreo' berarti tari. Dengan demikian, istilah etnokoreologi mengandung arti ilmu tentang tari-tari etnis. Narawati (2013: 70-71) menambahkan bahwa istilah etnokoreologi mengandung empat pengertian, yakni pertama tari adalah produk sebuah masyarakat. Kedua, tari sebagai produk masyarakat mengandung nilai-nilai yang dianut masyarakat. Ketiga, nilai yang dianut masyarakat satu dengan masyarakat lainnya itu berbeda. Keempat, menilai/ mengapresiasi sebuah tari etnis tidak bisa berlaku umum harus dengan acuan nilai yang dianut masyarakat pemilik budaya tarinya. Dengan demikian, maka teori etnokoreologi lebih menekankan bahwa tari merupakan produk masyarakat yang tentunya terkandung nilai-nilai etnis di dalamnya.

Penelitian ini menggunakan teori etnokoreologi, karena penelitian ini menitikberatkan terhadap nilai-nilai kasundaan yang terkandung dalam tari Pakujajar. Tari Pakujajar merupakan tarian yang berasal dari Kota Sukabumi yang berada di daerah Sunda, sehingga nilai-nilai yang terkandung dalam tari Pakujajar pun mengacu terhadap nilai-nilai kasundaan. Nilai-nilai kasundaan tersebut terdiri atas cageur, $b a-$ geur, bener, pinter, tur singer. Nilai-nilai $k a-$ sundaan dalam tari Pakujajar dapat terlihat dari berbagai aspek, yakni secara tekstual dan kontekstualnya.

Sumiati (2012: 52-66) menyatakan bahwa karakter atau sifat menunjukkan suatu identitas visual dan mencerminkan ciri yang khas dari seseorang. Dengan demikian karakter mencerminkan jati diri dari seseorang atau bahkan karakteristik dari suatu tarian. Berdasarkan kajian secara tekstual, tari Pakujajar tergolong pada tarian yang berkarakter gagah, karena karakteristik gerak tari Pakujajar lebih cenderung menggunakan ruang gerak serta volume gerak yang besar dan tenaga yang kuat. Gerak-gerak dalam tari Pakujajar pun tergolong pada kriteria komposisi tari yakni locomotion (gerak berpindah), baton signal (gerak penguat ekspresi), pure movement (gerak murni) dan gesture (gerak maknawi). Di samping itu, tata rias dan tata busana tari Pakujajar mencerminkan karakter pria yang gagah dan kuat. Selanjutnya, berdasarkan kajian kontekstual, yakni menurut aspek sejarahnya, tari Paku- 
jajar memiliki karakter gagah, berani, dan rela berkorban. Hal tersebut terlihat dari tokoh prajurit dan Wangsa Suta yang gagah, berani, tangguh, serta rela berkorban dalam menyelamatkan sesama. Dengan demikian, tari Pakujajar mengandung nilai-nilai yang sesuai dengan nilai kasundaan, yakni cageur, bageur, bener, pinter, tur singer. Hal tersebut sejalan dengan penelitian Indrayuda (2013: 270280) mengenai tari piring, sebagai berikut:

"Tari Piring telah menjadi identitas kesukuan bagi masyarakat Minangkabau perantauan, sehingga mereka merasa memiliki peradaban dan jati diri yang dapat mereka banggakan. Oleh karena itu, mereka berusaha memelihara Tari Piring dalam kehidupannya di perantauan."

Pernyataan di atas relevan dengan tari Pakujajar yang merupakan identitas masyarakat Sunda, khususnya Kota Sukabumi, karena tari Pakujajar mengandung nilai-nilai kearifan lokal yang berkaitan dengan karakteristik masyarakatnya. Hal tersebut dapat terlihat dari unsur gerak tari, musik, tata rias, tata busana, serta sejarah dan makna dari berbagai simbol yang terdapat dalam tari Pakujajar. Berbagai unsur tersebut dapat terkupas melalui teori etnokoreologi.

\section{Pendidikan Nilai}

Pendidikan nilai memiliki peranan penting dalam mewujudkan manusia yang seutuhnya. Lickona (2012: 31) menyatakan sebagai berikut.

"Suatu masyarakat membutuhkan pendidikan nilai baik untuk penyelamatan maupun perbaikan untuk tetap bersatu di dalamnya dan untuk maju bersama dalam menyesuaikan dan mendukung kehidupan dan perkembangan manusia sebagai bagian dari masyarakat tersebut."

Pendidikan nilai merupakan suatu hal penting demi mengubah hidup manusia lebih baik lagi. Dewasa ini, terdapat fenomena yang terjadi akibat dari terkikisnya nilai-nilai yang mengarah pada nilai moral atau nilai karakter. Hal tersebut berkaitan pula dengan nilai-nilai lokal yang sudah mulai luput dari peradaban masyarakat, sehingga masyarakat kurang memerdulikan atau terkesan acuh terhadap nilainilai lokal yang ada. Nilai-nilai lokal yang menjadi contoh adalah nilai-nilai kasundaan yang sudah mulai terkikis, karena semakin lemahnya nilai-nilai etika serta estetika masyarakatnya.

Pada kajian teori tentang nilai-nilai $k a-$ sundaan, telah dipaparkan mengenai nilainilai yang terkandung di dalamnya yakni cageur, bageur, bener, pinter, tur singer. Nilainilai tersebut sudah mulai terkikis sehingga diperlukan sebuah pendidikan untuk menanamkan nilai-nilai tersebut. Pendidikan nilai merupakan salah satu upaya untuk mengupas permasalahan yang berkaitan dengan terkikisnya nilai-nilai tersebut. Lickona (2012) mengemukakan pentingnya tiga komponen karakter yang baik (component of good character) yaitu moral knowing (pengetahuan moral), moral feeling (perasaan moral), dan moral action (tindakan moral).

Berkaitan dengan tiga komponen moral yang dikemukakan Lickona (2012), Sudaryat (2015: 137) mengemukakan bahwa terdapat terdapat catur tunggal watak, yaitu (1) nilai karakter olah hati, (2) nilai karakter olah pikir, (3) nilai karakter olah raga dan kinestetik, dan (4) nilai karakter olah rasa dan karsa. Dengan demikian, ketiga komponen karakter tersebut berkaitan dengan empat pondasi nilai karakter, yaitu olah hati, olah pikir, olah raga, dan olah rasa atau karsa.

\section{Kecerdasan Majemuk (Multiple Intelligence)}

Dalam menanamkan nilai-nilai kasundaan (cageur, bageur, bener, pinter, tur singer), tentunya melibatkan tidak hanya satu kecerdasan saja, namun melibatkan beberapa macam kecerdasan. Gardner dalam Armstrong (2013: 6) menyatakan bahwa 
kecerdasan lebih berkaitan dengan kapasitas/kemampuan untuk (1) memecehkan masalah-masalah dan (2) menciptakan produk-produk dan karya-karya dalam sebuah konteks yang kaya dan keadaan yang naturalistik.

Selanjutnya, Gardner dalam Armstrong (2013: 6) menambahkan bahwa terdapat delapan kecerdasan yang dimiliki manusia, yaitu kecerdasan linguistik, kecerdasan logis-matematis, kecerdasan spasial, kecerdasan kinestetik-tubuh, kecerdasan musikal, kecerdasan interpersonal, kecerdasan intrapersonal, dan kecerdasan naturalis. Delapan kecerdasan tersebut tergolong ke dalam kecerdasan majemuk (multiple intelligence).

Multiple intelligence pun sangat berkaitan dengan nilai-nilai kasundaan (cageur, bageur, bener, pinter, tur singer). Beberapa kecerdasan yang memiliki keterkaitan dengan nilai-nilai kasundaan antara lain kecerdasan intelektual, kecerdasan emosional, dan kecerdasan spiritual. Jika dikaitkan dengan multiple intelligence yang digagas oleh Gardner, maka kecerdasan yang berkaitan dengan nilai-nilai kasundaan, antara lain kecerdasan lingusitik berkaitan dengan pinter, karena apa yang diucapkan harus seusia dengan hasil pemikiran yang jernih. Kecerdasan matematis-logis berkaitan dengan pinter, karena kecerdasan matematis-logis menitiberatkan pada aspek kognitif. Kecerdasan spasial berkaitan pula dengan nilai pinter, karena spasial berkaitan dengan kemampuan memahami dunia visual, di mana hal tersebut tentunya membutuhkan pemikiran. Kecerdasan kinestetik-tubuh berkaitan dengan nilai cageur dan singer, karena tidak terlepas dari kemampuan gerak dan tubuh dalam melakukan sesuatu. Kecerdasan musikal berkaitan pula dengan nilai pinter, karena berkaitan dengan kemampuan merasakan yang banyak menggunakan pemikiran. Kecerdasan interpersonal yang berkaitan dengan nilai bageur, karena lebih menitikberatkan pada kemampuan memahami perasaan orang lain. Selanjutnya kecerdasan intrapersonal lebih kepada penguasaan serta pengendalian diri sendiri, sehingga kecerdasan ini berkaitan dengan nilai bener.

\section{Pendidikan Karakter Berbasis Kearifan Lokal}

Pendidikan karakter merupakan pondasi utama bagi setiap manusia, tentunya bagi masyarakat di seluruh daerah. Astuti, dkk (2016: 90) mengemukakan sebagai berikut.

"Pendidikan karakter adalah pendidikan nilai, budi pekerti, moral, watak, yang bertujuan untuk mengembangkan kemampuan peserta didik untuk memberikan keputusan baik buruk, memelihara apa yang baik, dan mewujudkan kebaikan dalam kehidupan sehari-hari dengan sepenuh hati."

Pendapat tersebut menegaskan bahwa pendidikan karakter bertujuan untuk mengubah serta mengembangkan kemampuan siswa untuk menjadi lebih baik. Pendidikan karakter memiliki tujuan yakni menciptakan manusia yang beradab sesuai dengan nilai-nilai dan norma-norma yang berlaku di ranah masyarakatnya. Nilai-nilai budaya kearifan lokal memegang peranan penting untuk sebuah pendidikan, agar generasi penerus tidak serta merta meninggalkan budaya nenek moyangnya. Permasalahan yang melandasi penelitian ini yakni model pendidikan karakter Barat mendominasi model pendidikan karakter kearifan lokal. Mengenai hal tersebut, Wibowo dan Gunawan (2015: 14) mengemukakan bahwa bangsa kita latah dengan model pendidikan karakter ala Barat. Kita lupa bahwa kearifan lokal bangsa ini mengandung banyak nilai luhur yang tepat dan pas untuk membangun karakter anak didik di sekolah.

Pendapat tersebut menegaskan bahwa nilai-nilai kearifan lokal sudah mulai terkikis, karena perkembangan zaman dan perubahan pola pikir manusia. Tidak me- 
nutup kemungkinan bahwa nilai-nilai kearifan lokal memiliki banyak dampak guna mendukung perubahan karakter, pola pikir, kebiasaan manusia, dan tentunya diharapkan mampu membentuk serta membangun karakter manusia, khususnya bagi siswa sekolah. Dewasa ini, siswa sekolah, khususnya bagi para remaja, rentan dengan permasalahan terkait kenakalan yang dikarenakan oleh degradasi karakter. Dengan demikian, pendidikan karakter perlu ditanamkan serta dikembangkan, khususnya ketika pada masa remaja.

\section{METODE}

Metode yang digunakan dalam penelitian ini, yaitu metode action research dengan paradigma kualitatif, dengan memaparkan seluruh hasil penelitian. Metode action research menurut Kemmis dan Mc Taggart (1982) dalam Sukardi (2015: 3), sebagai berikut.

"Action research is the way groups of people can organize the conditions under which they can learn from their own experiences and make their experience accessible to others."

"Penelitian tindakan adalah cara suatu kelompok atau seseorang dalam mengorganisasi sebuah kondisi di mana mereka dapat mempelajari pengalaman mereka dan membuat pengalaman mereka dapat diakses oleh orang lain."

Penulis bertindak sebagai pendukung yang menaruh minat dan berkepentingan dalam proses atau lingkungan belajarmengajar. Dengan demikian, penulis merupakan orang luar yang mengumpulkan informasi serta memperbaiki cara mengajar guru. Pada dasarnya, penelitian tindakan atau action research lebih mengarah kepada cara mengajar guru serta cara belajar siswa, di mana hal tersebut merupakan cakupan dari komponen-komponen pembelajaran.

Action research terdiri atas empat tahap, di antaranya tahap perencanaan, pelaksanaan, pengembangan, dan tahap refleksi. Teknik pengumpulan data yang digunakan yaitu dengan melakukan observasi, wawancara, dan studi dokumentasi. Teknik observasi dilakukan dengan melihat kondisi sekolah, siswa, dan proses pembelajaran sebelum penulis melakukan penelitian. Selanjutnya, teknik wawancara dilakukan kepada koreografer tari Pakujajar, penari Pakujajar, kepala sekolah, guru Seni Budaya, dan siswa SMP Negeri 5 Kota Sukabumi.

Dalam menanamkan nilai-nilai kasundaan kepada siswa tentunya dibutuhkan indikator dari setiap nilai kasundaan. Nilai cageur memiliki indikator tangguh dan disiplin, nilai bageur memiliki indikator toleransi dan sopan santun, nilai bener memiliki indikator jujur dan disiplin, nilai pinter memiliki indikator cerdas dan kritis, dan nilai singer memiliki indikator aktif dan kreatif.

Indikator tersebut berasal dari analisis nilai-nilai kasundaan dengan nilai-nilai karakter yang terdiri atas beberapa sifat dan yang bersumber dari olah hati, olah pikir, olah raga, dan olah rasa yang tergolong ke dalam catur tunggal watak. Selanjutnya, dari setiap indikator disesuaikan pada nilai karakter berdasarkan analisis nilai-nilai kasundaan terhadap catur tunggal watak. Teknik analisis data yang digunakan yaitu reduksi data, penyajian data, dan verifikasi data.

\section{HASIL DAN PEMBAHASAN}

\section{Tari Pakujajar}

Tari Pakujajar merupakan sebuah tarian khas Kota Sukabumi yang bermula dari cerita legenda Kota Sukabumi serta berasal dari kisah perjuangan dalam mempertahankan kehormatan dan harga diri. Tarian ini ditarikan oleh pria yang menggambarkan kegagahan serta keberanian seorang pria. Gerakan-gerakan tari Pakujajar ini cenderung mengadopsi dari gerakan tari Keurseus yang biasa ditarikan oleh lakilaki. Tari Pakujajar identik dengan karakter kuat dan gagah. Dengan demikian, tari Pakujajar lebih banyak menggunakan 
tenaga yang kuat, volume dan ruang gerak yang besar. Soedarsono dalam Narawati (2003: 123) mengatakan bahwa volume gerak yang besar atau terbuka memberikan sentuhan emosional kejantanan.

\section{a. Karaktersitik Gerak}

Gerakan-gerakan yang terdapat dalam Tari Pakujajar di antaranya adeg-adeg, sirig, sembah, jangkung ilo, gedig, capang, nyawang, jalak pẻngkor (ẻngkẻng gigir), gedut, laras kon- da, dan mincid. Setiap gerakan tersebut dianalisi melalui teori Etnokoreologi. Setelah dikupas berdasarkan tekstual dan kontekstualnya, terdapat enam gerakan yang mewakili nilai-nilai kasundaan, di antaranya gerakan sembah, sirig, capang, nyawang, gedig, dan jangkung ilo. Nilai-nilai kasundaan yang terkandung dalam enak gerakan tersebut yakni sebagai berikut.

Tabel 1. Korelasi ragam gerak tari pakujajar dengan nilai-nilai kasundaan

\begin{tabular}{|c|c|c|c|}
\hline Nama Gerak & Makna Gerak & Nilai Kasundaan & Keterangan \\
\hline Sembah & $\begin{array}{l}\text { Melambangkan pem- } \\
\text { bukaan serta penghor- } \\
\text { matan }\end{array}$ & $\begin{array}{l}\text { Cageur, bageur, bener, } \\
\text { pinter, tur singer }\end{array}$ & $\begin{array}{l}\text { Sikap saling menghormati me- } \\
\text { ngandung nilai cageur, bageur, be- } \\
\text { ner, pinter, tur singer, karena meng- } \\
\text { gunakan fisik untuk berperilaku } \\
\text { baik serta pikiran untuk berpikir } \\
\text { jernih bahwa saling menghormati } \\
\text { itu adalah kewajiban manusia. }\end{array}$ \\
\hline Sirig & $\begin{array}{l}\text { Melambangkan kesi- } \\
\text { apsiagaan atau gesit } \\
\text { dan cekatan }\end{array}$ & Cageur, singer & $\begin{array}{l}\text { Sikap kesiapsiagaan, gesit, dan } \\
\text { cekatan membutuhkan fisik yang } \\
\text { kuat untuk bergerak serta keaktif- } \\
\text { an dalam mengerjakan sesuatu. }\end{array}$ \\
\hline Capang & $\begin{array}{l}\text { Melambangkan sikap } \\
\text { kewaspadaan dan ke- } \\
\text { hati-hatian, seperti hal- } \\
\text { nya kita sebagai manu- } \\
\text { sia harus berhati-hati } \\
\text { dalam memutuskan } \\
\text { serta memilih sesuatu. }\end{array}$ & Cageur, pinter, singer & $\begin{array}{l}\text { Sikap kewaspadaan mengandung } \\
\text { nilai cageur, pinter, tur singer, kare } \\
\text { na sebelum bertindak tentunya ha- } \\
\text { rus selalu dilandasi dengan pikir- } \\
\text { an yang jernih untuk mengambil } \\
\text { keputusan yang kemudian diapli- } \\
\text { kasikan dengan perilaku yang } \\
\text { baik. }\end{array}$ \\
\hline Nyawang & $\begin{array}{l}\text { Melambangkan sikap } \\
\text { kesiapan untuk mena- } \\
\text { tap masa depan yang } \\
\text { disertai dengan sebuah } \\
\text { perencanaan }\end{array}$ & Cageur, pinter & $\begin{array}{l}\text { Sikap kesiapan tentunya dilandasi } \\
\text { oleh pemikiran yang matang guna } \\
\text { mencapai tujuan yang diharapkan } \\
\text { di masa depan dan membutuhkan } \\
\text { fisik yang kuat dan sehat untuk } \\
\text { dapat bertindak. }\end{array}$ \\
\hline Gedig & $\begin{array}{l}\text { Mencerminkan sikap } \\
\text { percaya diri }\end{array}$ & $\begin{array}{l}\text { Cageur, bageur, bener, } \\
\text { pinter, tur singer }\end{array}$ & $\begin{array}{l}\text { Sikap percaya diri mengandung } \\
\text { nilai cageur, bageur, bener, pinter, } \\
\text { tur singer, karena membutuhkan } \\
\text { pemikiran yang matang untuk ber- } \\
\text { perilaku baik, dan fisik yang sehat } \\
\text { dan kuat untuk dapat menjalankan } \\
\text { apa yang telah dipikirkan. }\end{array}$ \\
\hline Jangkung ilo & $\begin{array}{l}\text { Melambangkan sikap } \\
\text { hati-hati, penuh per- } \\
\text { timbangan, dan intros- } \\
\text { peksi pada diri sendiri } \\
\text { (ngilo diri) }\end{array}$ & $\begin{array}{l}\text { Cageur, bageur, bener, } \\
\text { pinter }\end{array}$ & $\begin{array}{l}\text { Sikap kehati-hatian dan introspeksi } \\
\text { pada diri sendiri mengandung ni- } \\
\text { lai cageur, bageur, bener, tur pinter } \\
\text { karena sebelum bertindak tentu- } \\
\text { nya harus selalu dilandasi dengan } \\
\text { pikiran yang jernih untuk memper- } \\
\text { timbangkan sesuatu dan bercermin } \\
\text { pada diri sendiri agar dapat ber- } \\
\text { perilaku lebih baik. }\end{array}$ \\
\hline
\end{tabular}




\section{b. Tata Busana}

Tata busana yang digunakan dalam tari Pakujajar merupakan hasil perkembangan dari tari Putra Klasik. Pakaian serta aksesoris yang digunakan dalam tari Pakujajar yakni terdiri atas baju kutung, celana sontog, dodot, kẻwẻr, kacẻ, siger, iket, dan keris.

1) Baju kutung

Baju kutung merupakan busana yang digunakan dalam tari Pakujajar memiliki bentuk seperti baju pada umumnya, namun tidak berlengan. Baju kutung yang digunakan pada tari Pakujajar berwarna emas, hal tersebut dikarenakan warna emas dipercaya dapat memberikan keemasan dalam menggapai tujuan yang diharapkan. Permadi dan Fauzi (2011: 82) mengemukakan filosofi warna emas yang mengacu terhadap wayang kulit, yakni bahwa warna emas memiliki arti kemuliaan dan keluhuran. Dapat disimpulkan bahwa warna emas pada baju kutung yang digunakan dalam tari Pakujajar yakni melambangkan kesuksesan, kemuliaan, serta keluhuran seorang ksatria atau prajurit dalam menjunjung tinggi kehormatan kerajaannya.

2) Celana sontog

Celana sontog merupakan celana yang memiliki panjang sampai di tengah betis atau dapat dikatakan sebagai celana $3 / 4$. Celana sontog yang digunakan dalam tari Pakujajar berwarna hitam, yang melambangkan kegagahan. Sumarni (2001: 44) menyebutkan bahwa warna hitam melambangkan kemampuan menghadapi angkara murka, kuat, tegas. Hal tersebut sesuai dengan karakter yang diperankan oleh ksatria dalam cerita legenda Kota Sukabumi yaitu Wangsa Suta yang berjuang melawan angkara murka algojo demi menyelamatkan sesamanya. Dengan demikian, dapat dikatakan pula bahwa Wangsa Suta memiliki karakter yang agung dan bijaksana.

3) Dodot

Dodot merupakan kain yang digunakan sebagai kebawahan pada busana pria. Dodot yang digunakan dalam tari Pakujajar adalah dodot yang bermotif mega mendung. Tentunya motif mega mendung memiliki makna dan simbol. Kusumowardhani (2016: 20) mengemukakan sebagai berikut.

"Mega atau corak awan adalah bagaikan atap yang melambangkan langit. Pola corak diilhami dalam corak awan dalam kesenian Cina kuno. Penafsirannya dimaksudkan bagaikan awan hitam yang akan membawa hujan. Seperti halnya datangnya tirtamaya, yakni air yang memberikan kehidupan sebagai gejala alam yang sangat dihargai daerah Cirebon yang banyak menderita karena musim kemarau yang berkelanjutan."

Dengan demikian, dapat disimpulkan bahwa motif batik mega mendung melambangkan kesejahteraan serta kemenangan bagi setiap umat manusia. Tari Pakujajar menggunakan dodot yang bermotif mega mendung yang berasal dari Cirebon, sebagai salah satu bagian daerah di Jawa Barat, sehingga masih memiliki kesamaan dalam pola pikir serta pardigma para masyarakatnya.

4) Kẻwẻr

Kẻwẻr merupakan ikat pinggang yang digunakan sebagai pelengkap dalam tata busana tari. Kẻwẻr yang digunakan dalam tari Pakujajar terdiri dari dua yaitu kẻwér yang berwarna hitam dan emas serta kẻwér dari bahan batik yang bermotif parang rusak barong. Narawati (2003: 226) mengemukakan bahwa motif kain parang rusak hanya boleh dikenakan oleh karakter-karakter yang dalam stratifikasi kebangsawanan. Adapun kẻzwér yang berwarna hitam dan emas melambangkan kejujuran dan warna emas yang melambangkan kesuksesan dan kemenangan.

5) Kacẻ

Kacẻ merupakan pelengkap busana yang digunakan untuk menutupi dada. Kacẻ dalam tari Pakujajar terbuat dari bahan beludru berwarna hitam dan berbentuk "V" menjulur ke bawah. Kacé dalam tari Pakujajar lebih dominan dengan warna hitam yang melambangkan kejujuran, serta 
warna emas yang melambangkan kesuksesan dan kemenangan. Bentuk kacé tersebut menyerupai bentuk gunungan terbalik. Soemardjo (2014: 361) mengatakan bahwa Tribuawana gunungan adalah dunia manusia sebagai Dunia Bawah, genukan dan lengkeh sebagai medium penghubung manusia dengan Dunia Atas, jadi merupakan Dunia Tengah. Dengan demikian, maka antara Dunia Atas dan Dunia Bawah memiliki hubungan yang dihubungkan oleh Dunia Tengah atau dapat dikatakan bahwa dunia manusia memiliki keterkaitan dengan alam semesta dan juga alam kosong. Manusia sebagai makhluk yang tinggal di bumi dihubungkan dengan langit, yang dimana termasuk dunia atas.

6) Siger

Siger merupakan aksesoris yang dikenakan di kepala. Narawati (2003: 231) mengatakan bahwa siger merupakan hiasan pengikat kepala bagian bawah. Bentuk siger dalam tari Pakujajar membentuk seperti kujang. Kujang merupakan ikon atau lambang dari daerah Sunda. Selanjutnya, Kurniawan (2014: 30) mengemukakan tentang kujang, sebagai berikut.

“Kujang berasal dari kata Ku Jawa Hyang atau Ku Dyah Hyang, dengan tahapan: kujang asal kata dari Kudi Hyang atau Ku Dyah Hyang yang menunjuk kepada Ku Dayang Sumbi. Pernyataan tersebut sebagai wujud dari mulainya sistem ketatanegaraan di wilayah Nusa Kendeng atau Dwipantara (nama pulau Jawa saat itu). Salah satu nilai kujang terletak pada tingkat kelangkaannya."

Dengan demikian, kujang merupakan sebuah lambang yang di dalamnya terkandung nilai-nilai, yang tentunya nilai-nilai tersebut merujuk kepada nilai-nilai yang terkadung dalam budaya lokal daerah, yakni daerah Sunda.

\section{7) Iket}

Iket merupakan aksesoris yang dikenakan di kepala sebagai pelengkap dari aksesoris lainnya seperti siger. Iket berbahan dasar dari kain biasa yang dibentuk sesuai dengan kebutuhan. Suciati (2008: 239) mengemukakan sebagai berikut.

"Iket merupakan jenis tutup kepala tradisional yang terbuat dari kain dan dipakai dengan teknik tertentu seperti dilipat, dilipit, dan disimpulkan sebagai pengikat akhir. Iket dipakai oleh pria dari berbagai kalangan baik ulama, penghulu, pegawai pemerintah, masyarakat golongan bawah, mulai dari anak usia sekolah sampai orang tua, dan juga bangsawan."

Dalam tari Pakujajar, iket digunakan sebagai penutup kepala yang selanjutnya ditutupi dengan menggunakan siger. Iket yang digunakan yakni bermotif sama dengan dodot yang digunakan yaitu motif mega mendung yang berwarna cokelat, yang melambangkan kehangatan, natural, dan asri.

\section{c. Tata Rias}

Tata rias yang digunakan dalam tari Pakujajar adalah tata rias putra gagah. Hal tersebut terlihat dari bentuk alis, bentuk kumis, dan bentuk jambang. Dalam tata rias, terdapat ilmu yang mempelajari mengenai karakteristik rias, ilmu tersebut dinamakan pendekatan phisiognomi. Narawati (2013: 234) mengemukakan bahwa pendekatan phisiognomi adalah ilmu untuk membaca wajah dengan mempertimbangkan garisgaris mata, alis, mulut beserta kumisnya, dan bentuk hidung. Narawati (2013:237) mengemukakan bahwa secara phisiognomis, ksatria gagah dan dinamis memiliki mata yang agak terbuka dengan ujung mata lebih tinggi dari pangkalnya, bentuk alis yang besar, ujung kumis yang agak menjulang ke atas, dan bentuk hidung yang agak besar.

Dengan demikian, pendekatan phisiognomi disesuaikan pula pada karakter tarian serta karakter peran dari lakon atau penarinya. Jika dilihat dari tata riasnya, maka karakteristik rias dalam tari Pakujajar merupakan karakteristik putra gagah dan dinamis.

\section{d. Properti}

Properti tari merupakan peralatan yang digunakan sebagai pendukung dalam ta- 
rian. Properti digunakan dalam sebuah tarian dengan tujuan untuk memberikan esetetika atau nilai keindahan sesuai dengan kebutuhan dari tarian tersebut. Ismayanti (2013: 2) berpendapat bahwa properti tari adalah segala kelengkapan dan peralatan dalam penampilan atau peragaan dalam sebuah tari.

Pohon Pakujajar digunakan sebagai properti dalam tari Pakujajar berdasarkan filosofi secara tekstual dan kontekstualnya. Secara tekstual, pohon Pakujajar tersebut didasarkan atas bentuknya yang tegak lurus, sedangkan secara kontekstual, pohon Pakujajar didasarkan atas makna dan nilainilai yang terkandung dalam bentuk pohon tersebut. Seperti halnya bentuk pohon Pakujajar yang tegak lurus melambangkan semangat pemuda yang tangguh, kokoh, dan teguh pada pendirian, sehingga dari bentuk pohon tersebut dapat mencerminkan tekad lurus para pemuda yang bertindak sebagai ksatria dan prajurit di Kerajaan Pajajaran.

\section{Pembelajaran Tari Pakujajar}

Proses penanaman nilai-nilai kasundaan dilakukan melalui pembelajaran tari Pakujajar terhadap siswa kelas IX SMP Negeri 5 Kota Sukabumi. Pembelajaran tari Pakujajar yang dilakukan menggunakan tiga siklus dengan lima pertemuan, ketiga siklus tersebut berorientasi pada proses memahami, merasakan, dan melakukan, yang termasuk ke dalam teori Lickona yakni moral knowing, moral feeling, dan moral action. Proses memahami, merasakan, dan melakukan tersebut berkaitan dengan tiga aspek pembelajaran yang dicetuskan oleh Bloom yaitu kognitif, afektif, dan psikomotor, sehingga pada siklus pertama aspek yang lebih ditekankan yaitu kognitif (memahami), pada siklus kedua aspek yang lebih ditekankan yaitu afektif (merasakan), dan pada siklus ketiga aspek yang lebih ditekankan yaitu psikomotor (melakukan).

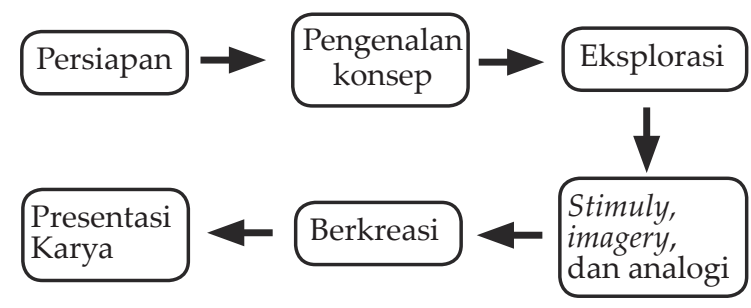

Bagan 1. Sintak model pembelajaran sinektik (Masunah, dkk., 2011: 72)

Tentunya, pembelajaran tidak terlepas dengan komponen-komponen yang terdiri atas tujuan pembelajaran, materi pembelajaran, metode/model pembelajaran, media pembelajaran, dan evaluasi pembelajaran. Model pembelajaran yang digunakan dalam pembelajaran tari Pakujajajar yaitu model pembelajaran sinektik. Hal tersebut dikarenakan model pembelajaran sinektik lebih menekankan terhadap pengembangan kreativitas siswa, dan pembelajaran tari yang diberikan kepada siswa yakni menggali kreativitas siswa untuk dapat merangkai gerakan menjadi sebuah tarian berdasarkan ragam gerak yang telah diberikan oleh penulis. Model sinektik yang digunakan terdiri atas beberapa sintak atau tahapan yang mengadopsi dari model sinektik yang telah dirancang oleh Masunah (2011).

Sintak dalam model pembelajaran sinektik terdiri atas persiapan, pengenalan konsep, eksplorasi, stimuli imagery dan analogi, berkreasi, dan presentasi karya. Dalam penelitian ini, penulis menggunakan sintak model pembelajaran sinektik yang mengacu pada sintak model pembelajaran sinektik yang dikemukakan Masunah. Namun, penulis menyisipkan tahap analogi ke dalam tahap eksplorasi, sehingga sintak model pembelajaran sinektik terdiri atas persiapan, pengenalan konsep, eksplorasi, berkreasi, dan presentasi karya.

Siklus pertama (memahami) terdiri atas satu pertemuan yaitu proses apresiasi video tari Pakujajar dan properti tari Pakujajar berupa pohon Pakujajar. Pada pertemuan ini siswa memahami dan menganalisis ni- 
lai-nilai kasundaan yang terdapat dalam tari Pakujajar. Proses pembelajaran dilakukan dengan menggunakan model pembelajaran sinektik melalui beberapa tahapan yaitu persiapan, pengenalan konsep, eksplorasi, berkreasi, dan presentasi karya. Pada tahap eksplorasi terdapat proses analogi. Analogi pada pertemuan ini melalui stimulus berupa pohon Pakujajar serta mengenai karakter tokoh yang terdapat dalam cerita Legenda Kota Sukabumi. Dengan demikian, siswa dapat memahami nilia-nilai kasundaan. Siswa melakukan diskusi dan kemudian mempresentasikan hasil diskusinya secara lisan. Pada pertemuan ini belum terlihat perkembangan dari setiap siswa, dan siswa masih kurang aktif berpartisipasi dalam proses pembelajaran.

Siklus kedua terdiri atas dua pertemuan yang terdiri atas proses pengenalan keenam ragam gerak tari Pakujajar dan pemahaman mengenai unsur-unsur tari yang terdiri atas ruang, tenaga, dan waktu. Proses pembelajaran yang dilakukan dalam setiap tahapan tentunya berbeda dengan siklus yang lainnya, karena disesuaikan dengan materi yang diberikan. Tahap eksplorasi yang dilakukan yaitu dengan melakukan analogi terhadap karakter tokoh-tokoh dalam cerita Legenda Kota Sukabumi seperti Wangsa Suta yang memiliki sifat tangguh, pemberani, dan rela berkorban, Nyi Pundak Arum yang berkarakter lemah, dan algojo yang berkarakter serakah. Selain pada karakter tokoh, proses analogi dilakukan dengan menggunakan stimulus berupa hal-hal yang dekat dengan siswa dalam kehidupan sehari-harinya. Analogi tersebut dilakukan dalam penyampain materi mengenai unsur-unsur tari pada pertemuan ketiga, seperti halnya siswa beranalogi terhadap tempat yang besar, sedang, dan kecil dalam pemahaman tentang konsep ruang dalam tari. selanjutnya siswa beranalogi terhadap cara berjalan dan berlari dalam pemahaman konsep tempo yang termasuk unsur waktu dalam tari. Pada siklus dua ini siswa menghubungkan nilai-nilai kasundaan dengan kehidupan sehari-harinya melalui ragam gerak yang diberikan, seperti halnya gerakan sembah yang mengandung nilai $\mathrm{ca}$ geur, bageur, bener, pinter, tur singer memiliki makna penghormatan. Dengan demikian, siswa harus memiliki sikap saling menghormati terhadap sesama dalam kehidupan sehari-harinya. Selanjutnya, tahap presentasi karya dimana siswa menampilkan hasil diskusi dan latihan dengan kelompoknya, yakni berupa peragaan ragam gerak tari yang telah diberikan. Pada siklus kedua ini sudah terlihat perkembangan dari siswa, yakni siswa lebih aktif dalam pembelajaran, lebih berani mengutarakan pendapat, dan lebih peka terhadap teman-teman di sekitarnya.

Siklus ketiga terdiri atas dua pertemuan yang terdiri atas dari proses berkreasi dan penampilan hasil akhir kreasi siswa. Tahapan pembelajaran pada siklus ini lebih menekankan terhadap tahap berkreasi siswa, karena siklus tiga mengacu terhadap proses melakukan yang merupakan bagian dari aspek psikomotor. Proses analogi pada siklus ini melalui karakter tokoh-tokoh dari cerita legenda Sukabumi. Tahap berkreasi yang dilakukan yaitu siswa secara berkelompok mengembangkan serta merangkai gerak menjadi sebuah tarian yang berasal dari keenam ragam gerak Tari Pakujajar yang disesuaikan dengan pemahaman siswa terhadap unsur ruang, tenaga, dan waktu. Pada siklus ini siswa lebih dapat bebas berekspresi sesuai dengan keinginannya, dan tentunya penulis selalu mengawasi dan memberikan arahan.

Tahap presentasi karya pada siklus ini, siswa menampilkan hasil kreasi tari yang telah dipelajari dari pertemuan-pertemuan sebelumnya, sehingga kreativitas siswa dapat berkembang sesuai dengan konsep model pembelajaran sinektik yang menitikberatkan terhadap pengembangan kreati- 
vitas siswa. Pada siklus ketiga ini terlihat perkembangan yang terjadi pada sikap siswa. Siswa lebih semangat dan gigih untuk berlatih, siswa dapat lebih saling menghargai sesama temannya, dan siswa dapat mengemukakan gagasan ketika mengembangkan gerak.

\section{Hasil Penelitian}

Hasil penelitian ini merupakan hasil dari penanaman nilai-nilai kasundaan berbasis pembelajaran tari Pakujajar, berdasarkan dari proses pembelajaran dan hasil kreativitas siswa yang dibantu dengan menggunakan model pembelajaran sinektik. Hasil penelitian menunjukkan bahwa terjadi perkembangan yang signifikan pada diri siswa. Data yang diperoleh berasal dari instrumen penelitian yang terdiri atas kriteria-kriteria sikap siswa dengan nilai kuantitatif yang didapatkan. Penulis melakukan penilaian terhadap sikap siswa dari siklus pertama hingga siklus ketiga. Penilaian sikap siswa tersebut tercermin dari bagaimana siswa menangkap, berpartisipasi, serta kooperatif dalam pembelajaran. Penilaian yang didapatkan oleh siswa mengalami naik turun dari setiap pertemuannya.

Berdasarkan peningkatan dari ketiga siklus, maka dapat dikatakan bahwa jumlah kenaikan nilai pada setiap siklusnya tidak selalu sama, sehingga pada setiap pertemuan memiliki perbedaan untuk nilai tertinggi dan terendahnya.

\section{SIMPULAN}

Hasil yang didapat dari penelitian ini adalah model penanaman nilai-nilai budaya lokal melalui pembelajaran tari etnis. Nilai-nilai budaya lokal tersebut kemudian diimplementasikan ke dalam sebuah pembelajaran melalui tari etnis. Hasil pembelajaran dari penelitian ini berupa perubahan sikap siswa berdasarkan proses dan hasil kreativitas siswa. Hasil penelitian menun- jukkan bahwa pembelajaran tari Pakujajar telah berhasil menanamkan nilai-nilai $k a-$ sundaan dengan melestarikan tarian daerah setempat yang sudah luput dari pengetahuan dan kehidupan generasi muda yang tercermin dari perubahan sikap siswa yang terus meningkat berdasarkan nilai-nilai $k a-$ sundaan yang ditanamkan. Pembelajaran tari etnis dengan mengkaji materi secara tekstual dan kontekstual yang dilakukan terhadap siswa SMP Negeri 5 Kota Sukabumi bukan untuk membuat siswa menjadi pandai menari, melainkan lebih kepada pengetahuan akan pemahaman terhadap nilai-nilai budaya lokal yang direfleksikan melalui sebuah tari daerah setempat.

\section{Daftar Pustaka}

Armstrong, T. (2013). Kecerdasan Multipel di dalam Kelas. Diterjemahkan oleh Dyah Widya Prabaningrum. Jakarta: Permata Puri Media.

Astuti, K. S., dkk. (2016). Pengembangan Model Pembelajaran Karakter Beraasis Seni Nusantara. Proceeding Seminar Seni Budaya Antar Bangsa, (1), 89-97.

Firmansyah, I. (2016). Soekaboemi The Untold Story: Kisah dibalik Sejarah Sukabumi. Jakarta: Mer C Publishing dan Paguyuban Soekaboemi Heritages.

Indrayuda. (2013). Popularitas Tari Piring sebagai Identitas Budaya Minangkabau. Panggung, 23 (3), 270-280.

Ismayanti, N. F. (2013). Properti sebagai Media Stimulus untuk Meningkatkan Kreativitas Siswa. Ringkang, 1 (3), 1-6. Kurniawan, A. (2014). Kajian Historis dan Filosofis Kujang. Jurnal Itenas Rekarupa. 1 (2), 29-40.

Kusumowardhani, P. (2016). Identifikasi Unsur Visual Bentuk dan Warna yang Menjadi Ciri Khas Ragam Hias Batik Trusmi Cirebon. 7th Industrial Research, Workshop, and National Seminar (IRONS), (7), 17-25. 
Lickona, T. (2012). Educating for Character (Mendidik untuk Membentuk Karakter). Diterjemahkan oleh Juma Abdu Wamaungo. Jakarta: Bumi Aksara.

Masunah, J., dkk. (2011). Pengembangan Model Pendidikan Seni Bagi Siswa Berkebutuhan Khusus. Bandung: Sekolah Pascasarjana Universitas Pendidikan Indonesia.

Narawati, T. (2003). Wajah Tari Sunda dari Masa ke Masa. Bandung: P4ST UPI.

-----------. (2013). Etnokoreologi: Pengkajian Tari Etnis \& Kegunaannya dalam Pendidikan Seni. Proceeding of the International Seminar on Languages and Arts, (2), 70-74. . (2013). Transformasi Nilai Budaya Sunda dalam Tari Keurseus: Dulu, Kini, dan Nanti. Makalah Konferensi Internasisonal Budaya Sunda (KIBS). Bandung.

Permadi, R. T. dan Fauzi, M. (2011). Perancangan Buku Warisan Budaya Wayang Kulit Indonesia. Inosains, 6 (2), 79-85.

Restela, R. dan Narawati, T. (2017). Tari Rampoe sebagai Cerminan Karakteristik Masyarakat Aceh. Panggung, 27 (2), 187-200.

Rustiyanti, S., Djajasudarma, F., Caturwati, E.. Meilinawati, L. (2013). Estetika Tari Minang dalam Kesenian Ran- dai Analisis Tekstual-Kontekstual. Panggung, 23 (1), 42-55.

Soemardjo, J. (2014). Estetika Paradoks. Bandung: Kelir.

Suciati. (2008). Karakteristik Iket Sunda di Bandung dan Sumedang Periode Tahun 1968-2006. ITB Journals Visual, Art, \& Design, 2 (3), 237-260.

Sudaryat, Y. (2015). Wawasan Kasundaan. Bandung: Jurusan Pendidikan Bahasa Daerah, Fakultas Pendidikan Bahasa dan Sastra, Universitas Pendidikan Indonesia.

Sukardi, H. M. (2015). Metode Penelitian PenPendidikan Tindakan Kelas: Implementasi dan Pengembangannya. Cetakan Ke-3. Jakarta: Bumi Aksara.

Sumarni, N. S. (2001). Warna, Garis, dan Bentuk Ragam Hias dalam Tata Rias dan Tata Busana Wayang Wong Sri Wedari Surakarta sebagai Sarana Ekspresi. Harmonia Jurnal Pengetahuan dan Pemikiran Seni, 2 (3), 37-49.

Sumiati, L. (2012). Tari Wayang Karakter Satria Ladak. Panggung. 22 (1), 52-66.

Wibowo, A. dan Gunawan. (2015). Pendidikan Karakter Berbasis Kearifan Lokal di Sekolah. Yogyakarta: Pustaka Pelajar. Yusuf, S. (2009). Psikologi Perkembangan Anak dan Remaja. Cetakan Ke-10. Bandung: Remaja Rosdakarya. 